\title{
Arabic Lexicography and the Holy Quran
}

\author{
Faleh Hassan Al-Asadi ${ }^{1}$, Abdul Rasul Awad ${ }^{2}$ \\ ${ }^{1}$ University of Babylon / College of Education for Humanities. E-mail: falihhassan1963@gmail.com \\ ${ }^{2}$ University of Babylon / College of Education for Humanities.
}

\begin{abstract}
The research tackles lexicographical phenomenon as it is considered to be one of the characteristics of Arabic calligraphy. Ancient and modern scholars differ about its origin between saying that its status was related to the status of Arabic letters or viewing it as a modern phenomenon. The research uncovers both views and discusses arguments and evidently reaches upon transferred, concrete and mental evidences, some firstly presented, that lexicographical dot is a subject that is part of Calligraphy and it is one of the defining characteristics of it.
\end{abstract}

Keywords:

Lexicography, Calligraphy, Inscriptions, Imam Ali (AS).

Article Received: 18 October 2020, Revised: 3 November 2020, Accepted: 24 December 2020

\section{Introduction}

One of the defining characteristics of Arabic letters in isolation is lexicographical dote and in collective form is parsing which is known as diacritics. The research will tackle lexicographical dots as existed with the existence of Arabic Calligraphy and as found within the writing of the Glorious Quran or without it [1]. What encourages us to approach such a topic is speeches said by Imam Ali (AS) that prove the existence of Lexicographical dot in his era like: "I am the dot under the extended Ba. I am the dot under the letter $\mathrm{Ba}$, I am the dot which is under B" and " The knowledge of the Quran is in Alfatihah and the knowledge of Alfatihah is in the Albasmalah and the knowledge of Albasmalah is in the $\mathrm{Ba}$, then he said "I am the dot under Ba' [2].

\section{Results and discussion}

The research is not concerned in explaining these speeches and analyzing them semantically but to prove that lexicographical dots phenomenon existed before Islam. This is in contrast with the idea that Nasr bin Asim (89H) was the first who put it or Yahya bin Ya'mur (90 or 127 or $128 \mathrm{H}$ ) or both as it was differently said. The discussion is as the following:

Abdufattah Abadah, Dr. Khaleel Nami, Dr. Ghanim Qaddoori Alhamd and Salih bin Ibrahim Alhasan believe that Arabs did not know lexicographical dots and parsing diacritics before Islam but they knew them in the time of Umayyad. That is to say, the first who used lexicographical dots for parsing the Holly Quran was Abu Alaswad Aldu'aly and the first who used dots for lexicology in the holy Quran was Nasr bin Asim Allaythy or Yahya bin Ya'mur or Abualhasan Albasry $(110 \mathrm{H})$ since they are contemporary to each other [3-7].

Al-Qalqashandi (T: 821 AH), Tashakbari Zadeh (T: 968 AH), Haji Khalifa (T: 1067 AH), Abu alTayyib al-Husayni al-Qanuji (T: $1397 \mathrm{AH}$ ), and Muhammad Taher al-Kurdi (T: 1400 AH), Dr. Jawad Ali, Dr. Nasser Al-Din Al-Asad, Dr. AbdelAl Salem Makram, Dr. Salah Al-Din Al-Munajjid, Dr. Muhammad Khair Al-Halawani, Dr. Yahya Wahib Al-Jabouri, and from the Orientalists Gerhard Anders, and KeesFresteg, all believe that lexicology arose with the Arabic calligraphy, and what Nasr and his companions did was to insert dotswithin the Qur'an, not inventdots [8-12]. This opinion is inferred by the following evidence, which can be classified into three sections:

\section{First: Transferred evidence:}

In addition to what has been mentioned above, the hadiths of Imam Ali (AS) and the other related ones prove the presence of lexicographical dots as in:

1 - What was narrated from him (AS), a sermon free from dots which reflects his awareness of dots 
and his distinction between dotted and non-dotted word. ((Taken from AbiSalih and AbiJa'far bin Babaweih based on Alridha and his fathers, Alkalbi narrated that the Companions gathered and substantiated that the Alef (A) is mostly used in speech then Imam Ali (AS) improvised his sermon which starts with (I praised whose beneficence is the greatest [13-15].

"Praise be to Allah the praise owner and shelter, to Him I affirm praise and taste it, I feel satisfied in praise and follow it, I purify praise and elevate it, I honor praise and prefer it. The only one the Self Sufficient Masterneither $\mathrm{He}$ has a father nor a son....". The sermon is too long [16].

2- What Tashkubry Zadah from Abdulrahman Albastami (858 AH) said is that "the first who talked about Quranic writing was Imam Ali bin AbiTalib, may Allah honor his face, as he said 'Basra destruction is by wind' with neglected ra' and ha' used between them the last letter ya'. He also recounted from Alhafidh Althehaby (748 AH) that he said: "This word has not been known as Quranic writing until the year two hundred (AH) and this means: Basrah destruction is by Zinj, zai, noon and jeem" [17]

Tashkebriy also said "Among the beautiful speech of Imam Ali bin AbiTalib, may Allah honor his face, is: "All grape the praise can give, which means that any defect is covered by praise. The Imam in this respect has grateful workmanships [18]. Imam's speech in this way is an evidence of his awareness of dots that are able to change letter form and meaning.

3- As Ibin Abbas (68 AH) said "Ali bin AbiTalib was explaining the dot under the letter $\mathrm{Ba}^{\prime}$ in the Aya "Inthe name of Allah the most Compassionate and Merciful' until the daybreak came but he did not complete his speech" [19,20]

Among the transferred evidences mentioned by advocators is the following:

4-What was mentioned in the pre-Islamic poetry is like 'alraksh (molting), alwashm (tattooing) and alraqm (numbering),. It is said 'I molted the writing to be molted [21]. If you wrote it and dot it as Tarfah said:

Molt it like the lines of Slavery At afternoon as molted be smelt.

The big Molted named as Rabee'ah:

The house is wild land and the drawings as crust molted by a pencil [22].

The book then "I doted it; I tattooed it, doted it with dots, lexicalized it and numbered it... As Abuthueib said:

By number and a tattoo as I redecorate it within its placenta is the prosperous guidance"

5-What was narrated from the prophet when he said "if you differ to decide upon the ya' and ta' try to write it ya"'. [23-25]

6-It was narrated from Ibin Abbas as he said: "The first who wrote in Arabic were three men from Bolan which is a tribe lived in Anbar. He said that Maramr bin Murrah, Aslem bin Sidrah and Amir bin Jidrah gathered and put separated and connected letters. Maramr put images, Aslem separated and connected and Amir put lexicography" [24]. It is said that they learnt Calligraphy from the prophet Hood Oracle writer then they taught it to Anbarians therefore, there is no contradiction with what the research adopted concerning the form of writing [25].

7-What was narrated from him is that "a light is from everything and the book is lexicography"

8-What was narrated that the writer of Ma'awyah (78AH) said "I wrote for Ma'awyah a letter and he told me 'mottle your letter Obeid, I wrote a letter for the prophet which I mottled'. I said 'what a kind of mottle commander? He replied 'give each letter the number of dots you intend to' [26].

9-It was narrated from IbnMas'ud (32AH) that he said "strip the Holy Quran to make your junior grow within it and never let your senior be dissociated" [27]. AS narrated from Omar bin Alkhattab (23AH) as he said to some people 
planning to go to Iraq "strip the holy Quran". The meaning of the word 'strip' is controversial.

Abo Obeidah (224AH) said "people differ in interpreting his speech 'strip the holy Quran' where Ibrahim thought that it was to put dots when writing the holy book so that he said 'strip the holy Quran and do not mix it with other books". He also said that Ibrahim hated to accept that because he was afraid of the existence of a new generation that is aware of the holy book as dotted then they believe that dots are part of the holy Quran [28]. Therefore, he hated those who refused the Apertures and Tenths. Many people agreed with such an idea that one may learn it alone and leave the Hadeeths. Abo Obeidah also said 'I do not oppose this as a slave to Allah having a desire to have this since he narrated from the prophet too much but I regard it as what Ibrahim regarded it". Ibrahim Alharbi (285AH) said "there are two possibilities: the first is to strip the holy Quran in the recitation and not to mix it with others and the second is to strip it in Graphically from dots and tenths." Alzeil'y (762AH) and Alzurkushi (794AH) chose the second [29].

Alzamekhshari (538AH) said " He wanted to strip from dots, Apertures and Tenths" while IbnAlatheer (606AH) said "he wanted to strip it from dots, parsing and the like". It deserves mentioning here that HafniNasif and Abo Abdullah Alzinjani believe that Lexicology existed with the Arabic Calligraphy but Lexicographical dots were not used within Othman's period (35AH). They interpreted stripping as to separate it from dots but they believed that the dots used at the Companions time were language specific signs which people could use to read [30]. They did not present any evidence to prove that but their suggestion has been refuted by the above evidences and the following as well [31].

Abo Omar Aldani (444AH) justified holy copies stripping saying. " The Senior emptied the holy copies from dots and images because they wanted to refer to the capacity of language and reading expanse.... the case was so until dotting and framing needs existed". He believes in the existence of dots and frame before Othman bin
Affan but the Companions fabricated it where he believed that as narrated by Qutadah (118AH) "they started then dotted then made fifths and tenths". This proves that the Companions and Senior Followers themselves who started to dot and drew fifths and tenths. Qutada's story did not suit except the Followers because he was one of them by saying "they started ...etc. until the end of his evidence which was an agreement among their Companions". He denied the existence of dots and images before Islam in that "Images and dots were not used by Arabs but they visualized diacritics as letters because parsing may be within it (Biha) is as the same in within them (Bihunna) [32]. Therefore, to visualize Fathah (Aperture) as Alif, Alkasrah as ya' and Aldhammah as waw reflects the same connotation reflected by the three diacritics themselves. What supports the idea that Arabs were not of images and dots is their use of letters to distinguish similar images like the use of waw in Amro to identify it from Omar. They annexed it in Ola'ika to distinguish it from Ileika where in the first they distinguished between it and Ilayah. They also annexed Ya' in " to distinguish between the hand that means power and the hands that is a plural of hand. They also annexed ALif (one hundred) to distinguish it from Minhu, Minnah and Miyah where the writing image is the same for these all" [33].

IbinAljazri (833AH) followed Aldani in justifying Quranic copies stripping as "when they wrote those Quranic copies they stripped them from dots and images to explain it correctly as narrated by the prophet; but they did empty the Quranic copies from dots and images to let the Calligraphical connotation of both recited audible transformed pronunciations be similar to the lonely semantic pronunciation for both logical understandable meanings". He also said "different readings may correspond the written form like: 'Ansaru Allah' (God's Supporters) 'NadathuAlmala'ikah' (Angels called him) 'Yagfirlakum' (forgive you) 'ya'maluun' (they know) heitalek' (come on oh you) etc. This proves that the holy Quran was stripped of dots and images. To confirm or neglect it especially in Orthography was the Companions' concern [34]. 
Doctor Alhamad denied stripping justifying this as

" Historical navels identify the ruling era of Abdulmalik and ruling era of Alhajjaj on Iraq as a non-suspicious beginning of using lexicographical dots in Arabic writing". In this respect he has forgotten the novels that prove the existence of lexicography before Caliph Othman that justify its stripping.

10-Alfarra's saying (207AH) "Sufyan bin AIInah who submitted it to Zeid bin Thabit, told me that he wrote using a stone 'nunshizuha' (Accumulate) and 'Yatasan' (Unchanged) where he looked at Zeid bin Thabit when dotted the Sheen and Zai with four dots and he wrote 'Yatasannah' (Unchanged) with ha" [35].

11-What Alsijistani narrated (316AH) that "Alhajjaj bin Yousif changed eleven letters in the holy book copy of Othman saying that the verse in Younus was (He it is Who spread you) and he changed it to (Younus: 22). It was also in Yousif (I will tell you it's interpretation)and he changed it to (Yousi 45). If it is supposed to accept what Alhajjaj changed (95AH)and he who dotted the word which was firstly not dotted then he changed it to be dotted because it may have two meanings if it is left undotted. There is no reason to say that Alhajjaj changed it [36].

\section{Second: Concrete evidences;}

1- A papyrus document found in Ahnas city in Egypt dated to (22AH-643AD) which was written in both Arabic and Greek in which the Arabic letters were 'dotted like Kha', Thal, Zai, Sheen, and Noon'.

2-Zuheir's inscription which is the oldest dotted inscription found in Shami Pilgrimage path in Alhijaz dated to $(24 \mathrm{AH})$ in which its writer dated the death date of Omar bin Alkhattab using dotted letters like 'Kha' Zai, Sheen, fa' and the noon'

3-The inscription of Ma'awia's dam dated to $(58 \mathrm{AH})$ is with dotted letters like 'ta', tha', kha', fa' noon and ya'.

4-The inscription of HafnatAlabyath found near Karbala and dated to (64AH) with dotted letters like 'ba', tha' and ya' [37].
5-Among the important discoveries during the recent century four sheets from the holy Quran discovered in Britain University of Birmingham (2015BA) include Verses from the SurasAlkahaf, Maryam and Taha. After investigated in Radioactive Carbon it is found that they are 1370 years old which means that they were dated to $(568,645 \mathrm{AD})$. This makes them the oldest copies of the holy Quran with dated letters like 'ba', ta', kha', zai, sheen, gein, noon and ya' [38].

\section{Third: Mental evidences;}

Among the mental evidences about the existence of Lexicology is that we do not find two Arabic sounds that pronounce a specific sound but there is a specific pronunciation for every sound which means that each sound has a specific letter. Therefore one may ask a question like; what is the benefit from putting two pronunciations for the same letter? For this we can say that since there are no two sounds that are similar in pronunciation with different connotation there are no two letters that are similar in shape with different connotation [39].

Another mental evidence is how a learner distinguishes similar letters? Is it to rely on the pronunciation only while he needs to learn writing? One also may ask about the benefit behind repeating the drawing of letters? Is it difficult to find a separate image for each letter although the inventor is so keen to put many images for all letters? If the goal is to avoid repetition for the sake of economy this may lead to a certain ambiguity in use while with Lexicography both abbreviation and clearness are achieved. Therefore, Imam Ali's (AS) speeches are another evidence added to the transferred evidences. We conclude that Lexicography existed with the existence of letters but it had been modified during Omayyad era [23]. The reason behind the absence of concrete evidences is that "all pre-Islamic writings found are just few letters and few words as inscriptions on stones. There is no writing with big number of words or lines found on leaf or papyrus. Not dotting might be because the writer was confident that his inscripted words were safe from copying and 
mixing in reading because they were nouns, years and easy words. It might also be justified that he neglected dotting because it was a hard task for him to inscript" Moreover, writing was commonly used which in the future may discover some inscriptions that contain lexicography which assures transferred and mental evidences mentioned above [22, 323, 35].

Doctor Alhamad did not feel confident for the three concrete evidences justifying that "the three documents that date to the previous period and contain the phenomenon could not be only a sufficient evidence of its existence". If we add other concrete with transferred and mental evidences, we can confirm its ancient existence since these evidences support each other [2].

\section{References}

[1] Abjad al-Ulum: Abu al-Tayyib Muhammad Siddiq Khan al-Qanuji (Tel: 1307 AH), Dar Ibn Hazm, Al-Hijaz, ed. 1,1423 AH-2002 AD.

[2] Stetkevych, Suzanne Pinckney. "Al-Sharīf al-Raḍ̄ and Nahj al-balāghah: Rhetoric, Dispossession, and the Lyric Sensibility." Journal of Arabic Literature 50.3-4 (2019): 211-250.

[3] Tayyara AE. Prophethood and Kingship in Early Islamic Historical Thought. Der Islam. 2008;84(1):73-102.

[4] JAMEEL SA. The INFLUENCE Of SCIENTISTS On The CALIPH ABDULMALIK BIN MARWAN BIOGRAPHY SCIENTIST QUBAISA BIN THUOUYB As A MODEL. ISLAMIC SCIENCES JOURNAL. 2020 Jan 31;10(6):146-56.

[5] Bruinessen M. Kitab kuning; Books in Arabic script used in the Pesantren milieu; Comments on a new collection in the KITLV Library. Bijdragen tot de taal-, land-en volkenkunde/Journal of the Humanities and Social Sciences of Southeast Asia. 1990 Jan 1;146(2):226-69.

[6] Versteegh K. Arabic language. Edinburgh University Press; 2014 May 20.
[7] Versteegh CH. Arabic grammar and Qur'ānic exegesis in early Islam. Brill; 1993.

[8] Hunwick JO, O'Fahey RS, editors. Arabic Literature of Africa: The writings of central Sudanic Africa Vol. 2. Volume 13. Brill; 1994

[9] Suleiman Y. The Arabic language and national identity. Edinburgh University Press; 2003 Jan 1.

[10] Lewis B. The political language of Islam. University of Chicago Press; 2018 Dec 14.

[11] Gacek A. The Arabic manuscript tradition: a glossary of technical terms and bibliography-supplement. Brill; 2008 Apr 9.

[12] Berkey JP. The transmission of knowledge in medieval Cairo: A social history of Islamic education. Princeton University Press; 2014 Jul 14.

[13] Aoun JE, Benmamoun E, Choueiri L. The syntax of Arabic. Cambridge University Press; 2009 Dec 3.

[14] Owens J. A linguistic history of Arabic. Oxford University Press; 2006 May 11.

[15] Neuwirth A. Qur'an and History-a Disputed Relationship. Some Reflections on Qur'anic History and History in the Qur'an. Journal of Qur'anic Studies. 2003;5(1):1-8.

[16] Rippin A, editor. Approaches to the History of the Interpretation of the Qur'an. Oxford: Clarendon Press; 1988.

[17] Sookhdeo P. Issues of interpreting the Koran and Hadith. Connections. 2006 Dec 1;5(3):57-82.

[18] Hoyland RG, Hoyland R. Arabia and the Arabs: From the Bronze Age to the coming of Islam. Psychology Press; 2001.

[19] Sobari, Jajang. Problematika Doktrin Keagamaan Salafi Kontemporer. Diss. Universitas Islam Negeri Alauddin Makassar, 2012.

[20] Dewey DP, Belnap RK, Hillstrom R. Social Network Development, Language Use, and Language Acquisition during Study 
Abroad: Arabic Language Learners' Perspectives. Frontiers: The interdisciplinary journal of study abroad. 2013;22:84-110.

[21] Ryding KC. A reference grammar of modern standard Arabic. Cambridge university press; 2005 Aug 25.

[22] Ashtiany, Julia, and Muh Badawi. Arabic literature to the end of the Umayyad period. Vol. 1. Cambridge University Press, 1983.

[23] Khalidi T, al-Khālidī Ṭ. Arabic historical thought in the classical period. Cambridge University Press; 1994.

[24] Chejne, Anwar G. The Arabic language: Its role in history. U of Minnesota Press, 1969.

[25] Ahmed, Sulaiman. The Disagreement between Avicenna and al-Ghazali on the Issue of the Pre-eternity of the Universe, how their Arguments Originated from Greek Philosophers and their Effect on Muslim Philosophers. Diss. University of Wales Trinity Saint David, 2017.

[26] Prochwicz-Studnicka, Bożena. "The formation and the development of the Arabic script from the earliest times until its standardisation." The Polish Journal of the Arts and Culture. New Series 9 (1/2019) (2019): 53-91.

[27] Farghaly A, Shaalan K. Arabic natural language processing: Challenges and solutions. ACM Transactions on Asian Language Information Processing (TALIP). 2009 Dec 1;8(4):1-22.

[28] Habash, Nizar Y. "Introduction to Arabic natural language processing." Synthesis Lectures on Human Language Technologies 3.1 (2010): 1-187.

[29] Abdulla NA, Ahmed NA, Shehab MA, AlAyyoub M. Arabic sentiment analysis: Lexicon-based and corpus-based. In2013 IEEE Jordan conference on applied electrical engineering and computing technologies (AEECT) 2013 Dec 3 (pp. 16). IEEE.

[30] Farra N, Challita E, Assi RA, Hajj H. Sentence-level and document-level sentiment mining for arabic texts. In2010 IEEE international conference on data mining workshops 2010 Dec 13 (pp. 11141119). IEEE.

[31] Shoukry A, Rafea A. Sentence-level Arabic sentiment analysis. In2012 International Conference on Collaboration Technologies and Systems (CTS) 2012 May 21 (pp. 546550). IEEE.

[32] Akkila, Alaa N., and Samy S. Abu Naser. "Teaching the right letter pronunciation in reciting the holy Quran using intelligent tutoring system." (2017).

[33] Owens, Jonathan. The foundations of grammar: an introduction to medieval Arabic grammatical theory. Vol. 45. John Benjamins Publishing, 1988.

[34] Abdelaal, Noureldin Mohamed, and Sabariah Md Rashid. "Grammar-related semantic losses in the translation of the Holy Quran, with special reference to Surah Al A'araf (The Heights)." SAGE Open 6.3 (2016): 2158244016661750.

[35] Suleiman, Yasir, ed. Arabic grammar and linguistics. Routledge, 2013.

[36] Gholitabar M, Kamali AD. The Quran and the development of Arabic linguistics. InInternational Conference on Language, Medias and Culture IPEDR 2012 (Vol. 33, pp. 26-30).

[37] Tabbaa, Yasser. "The Transformation of Arabic Writing: Part I, Qur'ānic Calligraphy." Ars Orientalis (1991): 119148.

[38] Gacek, Adam. Arabic manuscripts: a vademecum for readers. Vol. 98. Brill, 2009.

[39] Gacek, Adam. The Arabic manuscript tradition: a glossary of technical terms and bibliography-supplement. Vol. 95. Brill, 2008. 